\title{
Factors Influencing Museum Sustainability and Indicators for Museum Sustainability Measurement
}

\author{
Izabela Luiza Pop ${ }^{*, \dagger}$ and Anca Borza ${ }^{\dagger}$ \\ Received: 27 October 2015; Accepted: 15 January 2016; Published: 21 January 2016 \\ Academic Editor: Giuseppe Ioppolo \\ Economics and Business Administration, Babeş-Bolyai University, Strada Teodor Mihali, Nr. 58-60, \\ Cluj-Napoca 400591, Romania; anca.borza@econ.ubbcluj.ro \\ * Correspondence: izabela.pop@ubbonline.ubbcluj.ro; Tel.: +40-765-228-389 \\ + These authors contributed equally to this work.
}

\begin{abstract}
The purpose of this research was to identify the factors upon which museum sustainability depends and the way in which this can be measured. Methodologically, we applied a qualitative research approach, using semi-structured interviews with experts from the Romanian museum sector, complemented by an in-depth study of the literature in this field. Results indicated that any objective measuring of sustainability must take into account the size of a museum's collections and its organizational structure. It was also found that museum type can affect sustainability via its competitive advantage. However, the sustainability of a museum is not strictly determined by these factors, but also by the management and marketing strategies applied. Based on analysis of literature- and respondent-based factors influencing sustainability, this article proposes a set of 33 indicators that can be used by museums to measure their sustainability, as well as a model that enables evaluation of the sustainability levels of various museums comparatively, regardless of their type, size or importance (e.g., national, regional and local). The results obtained are useful both from a theoretical point of view, given that there are few writings on this topic, and from a practical point of view, as they provide a basis for a clear, objective model of museum sustainability measurement.
\end{abstract}

Keywords: sustainability; sustainable development; museums; indicators; performance; measuring model

\section{Introduction}

Even though, when the Brundtland report was drawn up in 1987, culture was not mentioned as one of the basic pillars of sustainable development, at present more and more studies emphasize the key role of cultural organizations in the process of sustainable development of a region [1-3]. These organizations can be engines of economic development (through cultural industries, cultural tourism, and traditional livelihoods), as well as contributor to social cohesion, natural environment sustainability and resilient communities. However, the degree to which cultural institutions contribute to these development goals is not sufficiently known [4], probably due, in part, to the lack of measuring instruments and adequate indicators. To be able to measure the contribution of cultural organizations to the sustainable development of a region, one must start with an analysis of these organizations regarding their own sustainability attributes and capacity to influence or mold sustainable behaviors. Special attention must be given to cultural heritage as a tangible element of culture and to museums as institutions created with the purpose of providing custody for cultural heritage [5].

Museums are complex non-profit cultural organizations [6-8] that differ a great deal from each other in terms of funding, size, type and collections. To supplement traditional museums, in recent years new types of museums have appeared, such as interactive museums [9], ecomuseums [10] and 
museums that do not own collections but are successful due to the cultural and educational services they offer to their visitors [11]. The complexity of museums as organizations results from their very aims of achieving, at the same time, both socio-cultural goals in relation to the conservation and interpretation of artifacts, and commercial goals in relation to spending associated with leisure time, tourism, and the increase of the museums' earned income [12].

To assure that they can achieve simultaneously their socio-cultural as well as their economic goals, some museums have become active in commercial aspects, being managed as privately-owned companies [13]. The reason for this transformation lies in the fact that the funds they attract for financing their socio-cultural goals, whether these are public or private funds, depend directly on the value the museums offer to the public $[14,15]$. Moreover, since the financing sources depend on the museums' public performances, their traditional functions, such as collection, conservation and research of the region's heritage [16], must be complemented by some extrinsic functions [17], which relate to the social, educational, cultural-artistic and economic benefits [18] generated by these organizations.

Diversification of museums' functions is characterized by expanding the traditional role, i.e., keeping and researching cultural heritage [19], to include, directly or indirectly, new roles, such as functioning as: venues for experience sharing [6], spaces for interaction, playing or education [20-23], instruments of mass culture communication that contributes to improvement of social life [24,25], engines for economic development of their respective communities [26], tourist attractions within cultural centers [27], sources of income, and instruments for manpower employment [14]. The new functions and roles that museums have to play, therefore, justify the accent laid on consideration of these institutions as important resources for territorial development [28].

All these new roles are closely connected with the notion that cultural organizations can and must make a contribution to sustainable development. Starting from this as yet insufficiently valued potential of the cultural sector, the purpose of new public policy is to use the heritage as a resource for economic growth (in general, through tourism) [29], and to apply such strategies as to allow cultural institutions to increase quality of life and sustainable development through the use of heritage as a generator of cultural, social and economic values [30,31]. For example, the political-legislative frame of the United Kingdom has in view the reconfiguration of the social role of museums in such a way that their mission should include functions of fighting off social exclusion, and acting as vehicles for positive social change [32].

However, despite the evident connection between museums, culture and sustainable development [33], few researchers have explored the subject of museum sustainability and management [34]. Research on museums and sustainability generally has focused on defining the concept of museum sustainability, demonstrating the necessity of integrating this concept into the museum practices [3], and describing the ways in which various activities and measures adopted by museums have contributed or can contribute to enhancing the concept and practice of sustainable development. Because sustainable development is connected with the needs of current and future generations, and, so as to measure the progress that has been made, these needs must be assessed [35], Nielsen [36] had in view to provide support to the idea that the sustainability of a museum depends on the relevance of the respective museum for both the community and its visitors. This article extends Nielsen's research by analyzing other factors influencing sustainable museum development. More specifically, our research aims at providing answers to the following questions:

(1) Does the size of a museum (from the point of view of its collections and organizational structure) influence its sustainability?

(2) To what extent is sustainability influenced by museum type, taking into account that some museums are considered more attractive to the public than others?

(3) Is sustainability influenced by the application by museums of certain management and marketing strategies? 
(4) What indicators can be used for measuring a museum's sustainability so that the results obtained by different museums (from the point of view of their size and type) can be compared in an objective manner?

Therefore, the aims of this paper are to: (1) analyze the degree to which the type, size and management and marketing strategies applied by a certain museum can influence its sustainability; and (2) propose a set of indicators that would allow measuring and comparing the levels of sustainability of different museums. To reach these aims, we have conducted qualitative research, using semi-structured interviews with experts from the Romanian museum sector, and conducting an in-depth review of the literature on this topic. The first part of the paper synthesizes the most relevant conclusions drawn based on the bibliographic research about sustainable management of museums. The second part describes the qualitative methods used and the results obtained from interviews. The final section proposes a set of indicators upon which comparative analyses of museum sustainability can be conducted.

\section{Museums and Sustainability}

The economic recession, the increased competition in the leisure market and the reduction of public funding for cultural organizations are factors that have had a negative impact on the success of certain museums as tourist attractions [37]. For this reason, the use of practices that contribute to sustainability enhancement is regarded as an obligation of museums if they want to have sufficient resources available to survive and keep their collections in optimum condition [38].

Adoption of sustainable practices also helps museums fulfill their cultural mission of maintaining their collections for posterity [38]. The connection between sustainability and heritage preservation can be noticed in the definition given by The International Council of Museums (ICOM) as well. According to ICOM, "sustainability is the dynamic process of museums, based on the recognition and preservation of tangible and intangible heritage with the museums responding to the needs of the community. To be sustainable, museums, through their mission, must be an active and attractive part of the community by adding value to the heritage and social memory" [39]. Another relevant point of view is expressed by the Canadian Museums Association (CMA), which considers that a museum is sustainable if "it assessed the impact of its activities on the environment, on the quality of life of its stakeholders and on the economy" [40].

Thus, as any other organization, to become sustainable, museums must simultaneously consider economic, social, natural and cultural environments [3]. In fact, these elements can be considered the four pillars of sustainability. The maximum level of sustainability is attained when equilibrium among the four pillars, spheres [41], is achieved, as illustrated in Figure 1.

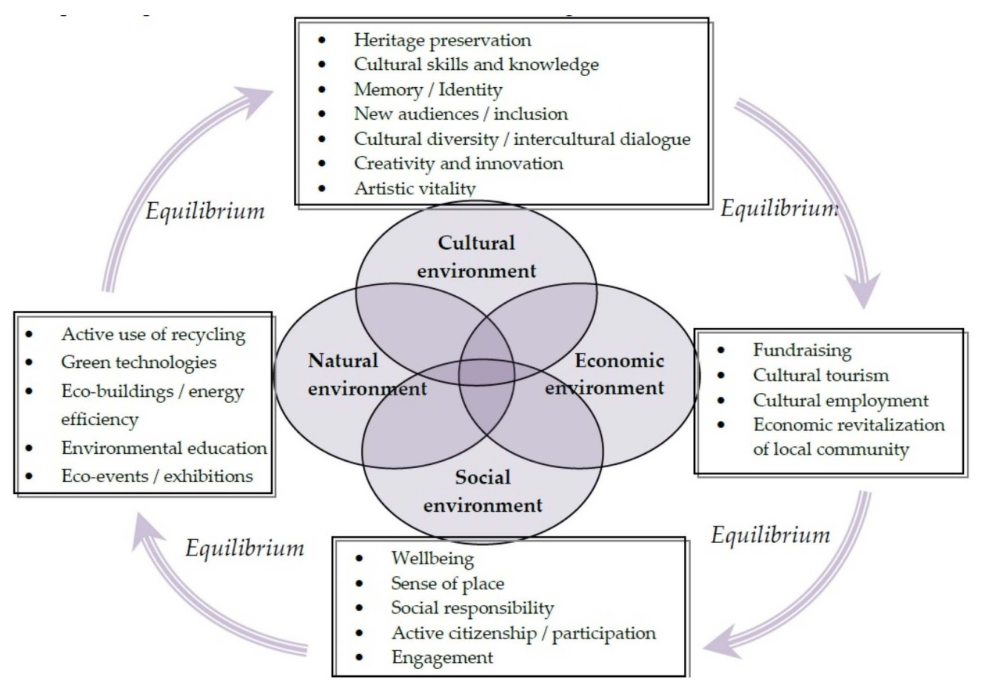

Figure 1. The four pillars of museum sustainability. Source: adapted after [33]. 
To achieve equilibrium, progress made in each of the four dimensions must be assessed regularly, which requires creation of valid, reliable and simple instruments of objective measurement [42]. Often increased performance in one of the dimensions creates negative effects on another dimension [42]. For example, small museums, with small collections and buildings consume less electricity than big museums, but they also have low financial and human resources [43]. Their negative impact on the natural environment is minor, which is good for this pillar of sustainability. Unfortunately, without enough people and significant collections, these museums probably will not be able to develop a lot of creative programs for different audiences; this has a negative impact on their socio-cultural sustainability. The economic pillar can be affected as well. Small museums employ fewer people than large museums and their attractiveness for tourists might be not high. Thus, in order to generate an output for the community, museums must use resources. In fact, when the emphasis is laid only on minimizing consumption, disequilibrium across the four components will occur. It might favor the natural environment, but automatically be to the detriment of the other dimensions (e.g., the cultural sustainability). For this reason, sustainability measurement indicators must be built in such a way as to account for the influences of each exerted on the other three dimensions; that is to say, the global effect of the phenomenon across all dimensions must be considered. However, for this, the role of museums in connection with each of the four pillars must be understood.

Socially, a museum has potential to impact positively not only on the lives of locals, but on those of its visitors as well, since it might contribute to change in their attitudes in connection with any matter, from wars to wildlife conservation [37]. This is done through the museum's function of educating its visitors. According to this function, the mission of museums is to provide access to life-long learning [44]. Due to the unique resources a museum holds for both formal and informal education [45], this function can be realized:

(a) Through classic activities, such as guiding or distributing information materials [46];

(b) Using heritage objects within participative and interactive programs [21];

(c) Organizing workshops and carrying out trans-disciplinary educational projects, together with educational organizations (such as kindergartens, schools, high schools and universities) [47]. These projects help students to develop such basic abilities as critical thinking, the capacity for analysis and synthesis, the ability to innovate and think creatively, and capacities for team work and collaboration [48].

The educational function can be complemented by new functions such as economic revitalization of communities [24] and recreational and entertainment functions [27,49]. These functions are directly connected with the museums' economic sustainability.

Museums' contributions to economic development has been demonstrated by many a researchers [50]. Museums play an important role in tourist development strategies of various regions and simultaneously contribute to the increase of residents' income and creation of jobs [51]. Swarbrooke [37] gives the example of a project through which a closed mine in Pendeen, UK was turned into a museum, which led to the creation of new jobs for residents, the valorization of the natural and cultural resources of the respective region, and the attraction of as many as 40,000 visitors per year. Wickham andLehman [52] asserted that, in 2009, in Australia, "domestic overnight cultural and heritage tourists injected" some 10 million Australian dollars into the economy and the visitors who attended the cultural and heritage activities spent an average of 1030 Australian dollars per stay. This was double the amounts spent by those who did not take part in such activities. Other researchers have emphasized that the museum sector's contribution to the British economy is bigger than that of the automotive industry or the publicity and film industry, and supports directly an estimated 195,000 full-time equivalent jobs [53]. In addition, it is estimated that, in Europe, museums attract 370 million visitors per year, the great majority of whom are tourists [51]. Due to museums' economic potential, more and more cities in both the U.S. and Europe create sustainable development strategies 
focused on cultural tourism [54,55], which makes Joshi [56] envisage the possibility of a strategic alliance between cultural organizations and tourism, with sustainability as a connecting bridge.

Thus, museums are more and more viewed as instruments of tourist flow promotion [57]. The contribution of museum heritage to the economic and socio-cultural development of a region through tourism has been recognized by both governments and various cultural organizations. This has led to the necessity of a deeper understanding of the way in which this sector can "deliver its economic and social returns more effectively and efficiently" [52].

Since another basic function of museums is the conservation and valorization of the cultural resources of a community, these institutions also contribute to the sustainability of their cultural and natural environments [58]. Besides the conservation of cultural resources, museums also have an important role in "protecting the local biodiversity" [31]. Through their educative function, the exhibitions they organize, and their involvement in discussions about the changes within their environment [59], museums might influence people's attitudes towards their natural environment as well [60].

Given the crucial importance of sustainability for both a museum's success and the welfare of the community where it is located, the understanding of what represents "the most frequently espoused sustainability policies and practices" in this sector seems to be of vital importance in the current environment [52]. Unfortunately a number of studies have demonstrated that museum managers do not give much attention to sustainability aspects [37,38]. For many museums, an increasingly important challenge is to ensure their own sustainability [37]. As long as museums are unable to ensure their own survival and development, they cannot contribute to the sustainable development of their respective communities.

The reasons why museums place minimal importance on sustainability are diverse. Chitima [38] identified a set of reasons, such as: the lack of a "green policy"; the failure by the museum's management to adopt concrete measures to this end; the demotivation of museum staffs due to low salaries and the lack of resources needed in order to carry out the museum's activities appropriately; the inappropriate attitude of some staff as regards the use of public resources (some employees confuse their responsibilities for appropriate uses of public resources and their own resources; sometimes, they use the museum's resources in their own interest; in addition, they do not feel the responsibility to use the museum's resources to offer attractive programs and activities for visitors); lack of knowledge about sustainability; and lack of expertise in the field of collection conservation. Additionally, we posit that an impediment towards a museum's sustainable transformation is the lack of a clear, widely accepted system of indicators which would allow the museum's management to assess current status and/or progress.

The literature mentions various self-assessment methods, such as "sustainability audits" or checklists for the achievement of some sustainability standards [38]. However, these methods have a high degree of subjectivity and results obtained for various museums are not comparable. For example, Corsane [61] defined 21 evaluation indicators pertaining to eco-museums, which were described as a list of activities, actions and effects that museums can have on the society. Another assessment model, identifying five indicators, was proposed by Davis [62,63], as follows: unconventional territory adoption; in situ conservation and interpretation; management of the sites being carried out via liaison, cooperation and the development of partnerships; empowerment of local communities; and the potential for interdisciplinary and holistic interpretation.

According to ICOM, an important indicator for measuring a museum's success of becoming sustainable is its intellectual and financial autonomy [39]. The proportion of earned income (the income earned by museums through their activities such as: selling tickets and/or souvenirs, renting spaces, lending objects, etc.) in the total revenues of a museum is also used by Rentschler and Geursen to estimate the level of cultural entrepreneurship of museums [8]. The number of visitors in a year, acquisitions of heritage objects, exhibitions organized, and the publications edited are among other elements used by museums to assess their own activity [8]. However, it can be asserted that none of 
these elements is a cultural indicator. They do not reflect the community's cultural needs, opportunities and welfare, nor do they offer a quantifiable assessment of the cultural impact that the activities carried out by a museum have upon people. What these elements do offer is an image of the activity of museums as institutions, as non-profit corporate entities [39]. Thus, Douglas Worts stated that a relevant sustainability indicator would be the unitary cost of a visit to the museum, estimated as a ratio between the total costs of the institution and the total number of visitors [39].

The indicators proposed by Eleanor Adams [64] are also useful to assess the progress made by a museum in becoming sustainable, and some of them were included in our model as well. Some of her indicators are expressed in absolute numbers (e.g., total number of people to access the collection on-site in 12 months), which is why they cannot be used to measure the general level of sustainability of a museum (see the explanation given at the beginning of the Section 4.2.1). Then, how can museums know when they have reached a satisfactory level of sustainability? Or, should museums increase their number of visitors continually? Would it be good for all the four pillars of sustainability to continually increase the number of visitors? It has already been discussed that sustainability means equilibrium across the four pillars. Too many visitors can affect the quality of the services offered by museums. It can also represent a risk to proper preservation of the heritage for future generations. However, the question is: How can museums determine this equilibrium? In consideration of these aspects, this work aims at laying the bases of a system of indicators and a model which can be used for objective, quantifiable measurement of museum sustainability.

\section{Methods}

This research had two main goals. The first goal was to identify if certain factors, such as the size, the type, or the management and marketing strategies applied by a museum can influence its sustainability. The second goal consisted of proposing a set of indicators which would allow measuring the level of museum sustainability.

To achieve both goals, we used a qualitative approach by conducting seven interviews with experts from the Romanian museum sector. Additionally, for the second goal, we made an in-depth review of the literature on this issue.

For the empirical research, we conducted semi-structured interviews. The flexibility of the interview plan allowed in-depth analysis of the problems under scrutiny. All the interview's questions, developed based on the literature and authors' experience, were open-ended. The core questions included in the interview guide were: (1) To what extent do you think the size of a museum (number of objects in the collection, number of employees) can influence its sustainability? (2) In your opinion, is there any connection between sustainability and the type of a museum (e.g., history, art, ethnography, natural history)? (3) In your opinion, is there any connection between sustainability and the number of visitors recorded by a museum? (4) In your opinion, is there any connection between sustainability and the earned income of a museum? (5) To what extent do you think the use of management and marketing strategies by museums can help increase their sustainability? (6) How can we assess if the measures adopted by a museum contribute to the enhancement of its sustainability? (7) What kind of indicators could we use in this regard?

Depending on the answers received to the initial questions, several extra questions were asked. At the beginning of each interview, respondents were informed about the purpose of the research and asked about their agreement to record the interview. In addition, the definition given for "sustainability" by ICOM was presented to respondents before addressing the questions.

The interviews were conducted according to the methods designed by Kvale and Brinkmann [65]. To assure the confidentiality of responses, the interviewed experts were coded randomly with letters A through G. The interviews were carried out during 2014-2015. The duration of the interviews was between $17 \mathrm{~min}$ and one hour, depending on the time availability of the respondents. Tape-recorded interviews were transcribed. Content analysis was used for identifying key words and paragraphs. 
The transcripts were analyzed by using a hybrid approach of deductive and inductive thematic analysis [66]. Subsequently, the most relevant ideas were selected and presented in this paper.

For achievement of the first goal, relevant questions focused chiefly on the characteristics that can influence the sustainability of a museum, such as its organizational size and type. In addition, by asking questions about the relationship between the total number of visitors (both payers and non-payers), the museums' earned income and its sustainability, we were able to note whether the interviewed experts perceive the concept of sustainability as a whole, with all its four dimensions (economic, cultural, social, and natural environment). The last part of the interviews focused on identification of the indicators, which, in our experts' opinions, allow the measurement of the sustainability of Romanian museums, as well as the measures for increasing the level of sustainability.

The sampling frame for our research was all museums that are members of the National Network of Romanian Museums (NNRM). The NNRM includes 66 members, but only 64 are museums (two members are private art galleries). The classification of these museums, according to their type, is presented in Table 1.

Table 1. NNRM museums: type and importance.

\begin{tabular}{cccccc}
\hline Type & Importance & Municipal Museum & County Museum & National Museum & \multicolumn{2}{c}{ Total } \\
\hline Art & & 7 & 2 & 3 & 9 \\
Ethnography and folk art & 1 & 3 & 7 & $14.06 \%$ \\
History & 2 & 1 & 0 & 10 & $15.63 \%$ \\
Memorial & 2 & 1 & 3 & $4.69 \%$ \\
Mixed & 7 & 17 & 3 & 28 & $43.75 \%$ \\
Natural history & 0 & 3 & 1 & $6.38 \%$ \\
Technology & 0 & 0 & 20 & 64 & $1.56 \%$ \\
Total & 12 & 32 & $100.00 \%$ \\
\hline
\end{tabular}

Notes: * Mixed museums are very common in Romania. They possess and expose objects belonging to two or more types (e.g., art, history and ethnography; history and archeology; ethnography and natural history).

All the member museums of NNRM are public museums, financed from public money. Most often, national museums are financed directly by the Ministry of Culture; county museums are financed by county councils, and local museums are financed by local councils. Besides the subsidies they receive, these museums can attract additional sources of income (earned income) from visiting fees, souvenir sales, sponsorships, and other services they offer. It should be noted that there are very few private museums in Romania.

The experts who were interviewed were selected so that the answers they would provide should be as relevant possible. Since the goal of our research was to obtain insights into a phenomenon (museum sustainability) [67], experts were selected from the sampling frame based on their experience, expertise, knowledge and availability. Thus, we used a non-random sampling scheme, based on specific criteria, for selecting the seven respondents.

First, we selected key informants who hold or have held a leading position in NNRM. These people are usually connected with other international organizations of museums (such as ICOM), and their level of expertise in the field of museums is high, which is why they could express pertinent answers to our questions. Some of these people are currently working in museums. Some others either have worked in museums or collaborated with museums as self-employed professionals, so they have a rich experience in this sector. Second, we selected key informants who hold a management position in a member museum of NNRM. As can be seen in Table 2, two experts fulfilled both criteria.

Particularly, we focused on museums from Bucharest, Cluj-Napoca and Baia-Mare. Of the 64 member museums of NNRM, 10 museums are from Bucharest, four museums are from Baia-Mare, and four museums are from Cluj-Napoca. These cities are also three of the four finalists in the competition for the title of European Capital of Culture 2021 [68]. Based on these criteria and museum characteristics, we selected three experts from Bucharest, three experts from Baia-Mare, and one expert 
from Cluj-Napoca. The distribution of these experts according to the type of museum they represent is reflected in Table 2.

Table 2. Museums represented by respondents.

\begin{tabular}{ccccccc}
\hline Type & Importance & $\begin{array}{c}\text { County } \\
\text { Museum }\end{array}$ & $\begin{array}{c}\text { National } \\
\text { Museum }\end{array}$ & Total & $\begin{array}{c}\text { Leading Position } \\
\text { in NNRM }\end{array}$ & $\begin{array}{c}\text { Leading Position } \\
\text { in a Museum }\end{array}$ \\
\hline Art & 2 & - & 2 & $28.57 \%$ & 1 & 2 \\
Ethnography and folk art & - & 1 & 1 & $14.29 \%$ & 1 & 1 \\
History & - & 1 & 1 & $14.29 \%$ & 1 & 0 \\
Memorial & - & - & 0 & $0.00 \%$ & - & 1 \\
Mixed & 1 & 1 & 2 & $28.57 \%$ & 1 & 1 \\
Natural history & 1 & - & 1 & $14.29 \%$ & 0 & - \\
Technology & - & - & 0 & $0.00 \%$ & - & 5 \\
Total & 4 & 3 & 7 & $100.00 \%$ & 4 & \\
\hline
\end{tabular}

Despite the diversity (both horizontal and vertical) of the interviewed experts, the study has several limitations. One of the most important is that the sample of seven respondents did not represent all types of museums that are members of NNRM (memorial and technological museums were left out; they represent $6.25 \%$ of the total types of museums). In addition, our sample did not include experts from municipal museums because almost all museums from Bucharest, Cluj-Napoca and Baia-Mare that are members of NNRM, are national and county museums (94.44\%). However, this study brings important insights to understanding the factors that influence the sustainability of museums and the indicators and tools for quantifying it.

\section{Results and Discussion}

\subsection{Factors Influencing Museum Sustainability}

The first hypothesis of our study was that the sustainability of a museum is influenced by a set of internal factors which can not be altered easily by the museum's managers, among which are the size of the collections, the organizational structure and the type of the respective museum. However, a direct numerical comparison between the absolute values of indicators (for example, the number of visitors) obtained by two different museums which differ in terms of type and size (staff and collections) would be irrelevant and could not lead to establishing a ranking in view of their level of sustainability.

\subsubsection{The Relationship between the Dimension (Size) of a Museum and Its Sustainability}

As related to a museum's size in terms of number of staff (i.e., the museum's organizational structure), space managed by the respective museum, and the number of objects it holds (collection size), six of the experts we interviewed noticed the existence of certain connections, both positive and negative, between these elements and sustainability.

Considering that Romanian museums are understaffed, which affects the quality and quantity of their activities, expert D noted that the size of a museum (its organizational structure) reflects directly upon the respective museum's sustainability. Three experts (D, F and G) said that a museum with more employees has a greater capacity for developing activities that have a positive impact on sustainable development. Alternatively is the opinion expressed by expert B, according to whom the size of a museum is irrelevant when it comes to its sustainability, as the essential factor here is the management of the respective institution. The opinions of the other three experts acknowledge the complexity of the variables' influences on sustainability.

Expert A believes that, on the one hand, "a bigger size calls for a higher commitment and complexity and a higher involvement, therefore a bigger managerial effort" (meaning that the museum manager has to administer more resources and activities). Thus, "sometimes the museums with small staffs (not insufficient; just small staffs which are big enough to appropriately manage a museum) can be more efficient because, when an institutional problem which has to be solved arises, decisions are easier 
to make than in a corporation-type museum, where a number of individuals must analyse it, (thereby) delaying and bureaucratizing the process of decision making, diagnosing, and solution finding a great deal. For this reason a bigger museum is not necessarily a stronger and more sustainable museum".

However, on the other hand, the same expert considers that "a bigger museum in terms of collection value is a museum which often times naturally goes on well" (it has many visitors and is attractive for the public). An example is the Pergamon Museum in Berlin where, this expert considers, nothing can be found of what is incorporated in Total Quality Management (e.g., spaces of creativity, spaces of interaction, information explained interactively). Despite this, "people troop in large numbers because the value of the collection is enough". Thus, museums of this type become sustainable economically without anything being done for this purpose. Related to their economic sustainability, this expert groups museums into two categories:

(a) "museums which are and always will be sustainable due to what they offer in terms of collections and no more than that;

(b) museums which become sustainable through innovation, proposition of revolutionary things (for example, the Victoria and Albert Museum which permanently innovates things, from the curatorial level and the conceptualisation of an exhibition up to the services it provides)".

Expert E also considers that the size of a museum and its sustainability are interdependent, without saying if this interdependence is direct or reverse. On the one hand, "the bigger and more diverse a museum, with the more human resources and more heritage, the bigger its possibilities of addressing the public, and the higher the chances of it being sustainable, which impacts on its development. At the same time, such a museum has bigger difficulties in maintaining its sustainability since it requires bigger financial and human resources." We can infer from this expert's assertions that the size of a museum could have a direct connection with socio-cultural sustainability and a reverse connection with economic sustainability. Moreover, this expert emphasizes that in the interaction of these two elements "there is somewhere a critical point" (of equilibrium), beyond which the type of connection reverses.

Expert $C$ believes that a bigger museum can exert a bigger social impact (and implicitly it can obtain higher income for financing its cultural activities) than a smaller museum, but it also consumes more resources in comparison with a smaller museum which, on the one hand "consumes less from all points of view", and on the other, has a very clearly defined target public, which allows it to develop a more consistent and relevant relationship with its public. Therefore, given these opposing influences, this expert believes that sustainability depends rather on the internal dynamics of the museum than its size.

Regarding another opinion expressed in the literature, one can note a tendency to consider that the development of a museum's collections has a negative impact on its sustainability, as it is often not accompanied by a similar development of its capacities of research and exhibition [70]. Thus, bigger collections generate bigger conservation and storage costs which often do not result in higher output generated on the market in the present and, moreover, "they are compromising the ability of future generations to meet their needs by passing on these collections for them to look after, having added even more material to them" [69].

However, we consider that the solution proposed by Merriman [69], deaccessioning the less important objects as the museum acquires new objects, is beneficial only from the point of view of the museum's short-term internal economic sustainability. Over the long term, such a policy can have a negative impact on both the economic sustainability and the socio-cultural sustainability of a museum. Even though the expansion of a museum's collections generates higher operational costs, in the long run bigger collections have the capacity of contributing to increased sustainability of the respective museum. Firstly, the importance of a museum increases as its collections are bigger and bigger, which might help attract a larger number of visitors. Secondly, keeping a larger quantity of cultural resources for future generations might have a positive impact on the cultural sustainability 
of a museum. A bigger collection allows a museum to better reflect the identity of a community and the changes that occurred over time in society. Thirdly, larger collections could lead to higher future economic and social benefits for the community.

As can be noted from Figure 2, the function of collecting heritage objects is essential since it provides a museum with "raw materials", thereby creating the premises for subsequent functions to be fulfilled, including the function of helping the community's sustainable development. All the other functions are dependent on this function, given that no conservation, research or exhibition is possible without a collection [46]. The second function, conservation, is necessary for the keeping the museum's "raw materials" (the museum's collections) in optimum condition so that these can be studied and used by present and future generations.

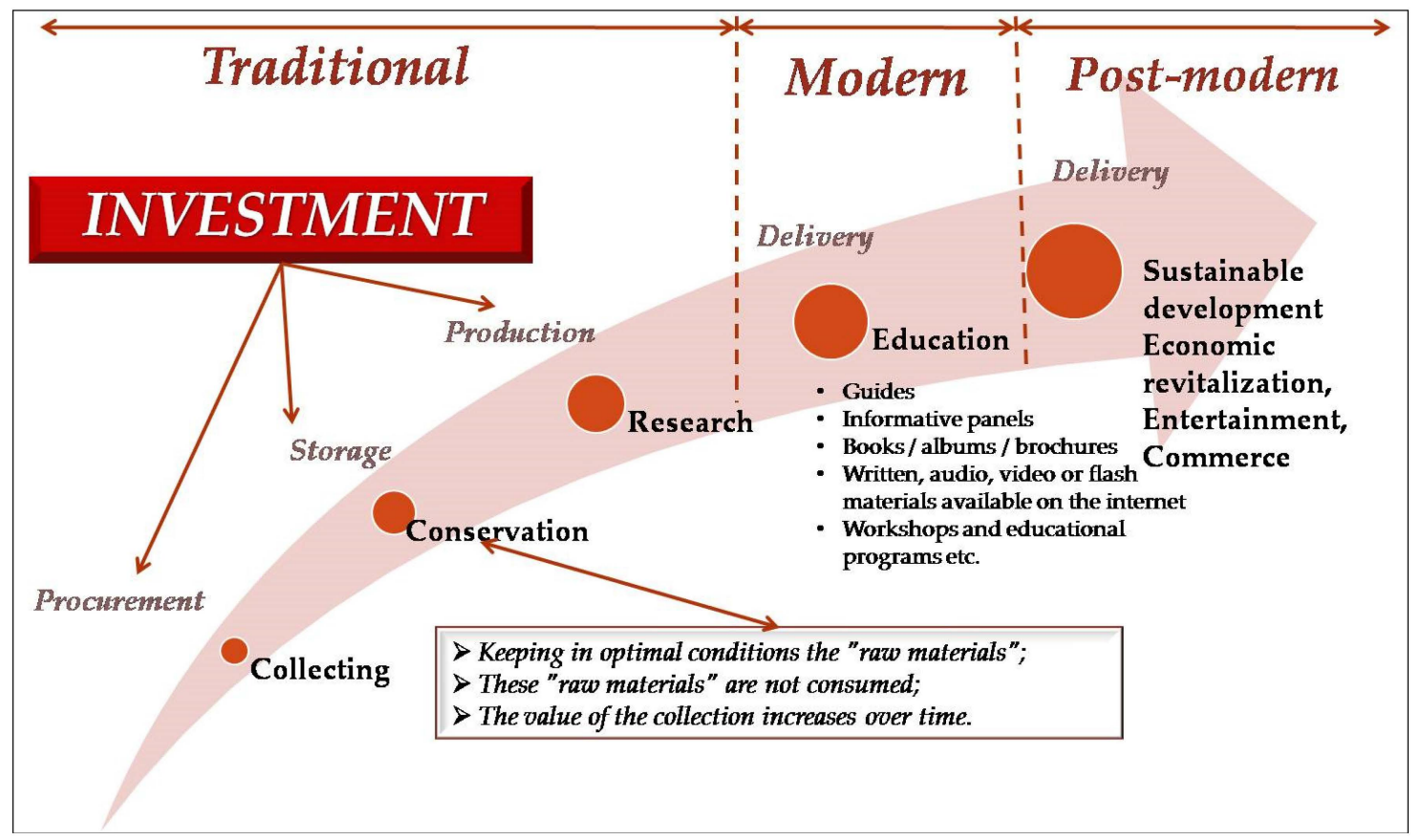

Figure 2. The evolution of museum functions. Source: the authors' contribution.

Therefore, the expenditures made for achieving these two functions should be regarded as investments made with the purpose of obtaining more benefits in the future. Even if a museum valorizes its collections only to a small extent through exhibitions and public programs, the mere conservation of these collections can be beneficial for the community since the value of most heritage goods can increase in time. For this reason, art museums, but not only these, can be regarded as financial institutions which, through their collections, contribute to increasing the national wealth.

Therefore, the size of the collections and that of a museum's organizational structure can impact significantly on its sustainability, both positively and negatively, depending on the way in which they combine with other internal and external factors. However, these opposing influences are not likely to be equal. Hence, we consider that a museum's size should be taken into account in the process of sustainability indicator elaborating, so as to assure compatibility of data obtained from a several different museums and a realistic view of a certain museum's sustainability.

\subsubsection{The Connection between Sustainability and a Museum's Type}

Regarding the connection between sustainability and a museum's type, expert A asserts that some museums have certain competitive advantages given by the professional domain within which they operate. For example, through their specificity, museums of natural science are more attractive for the young public. Despite this, the expert's opinion is that this advantage can easily be reduced or 
eliminated by other museums if the latter put their innovativeness and creativity to work and create museum spaces of social interaction.

Based on his personal experience, expert B considers that there is no connection between sustainability and a museum's type: "we saw cases of museums which were considered difficult (they failed to attract the public), but changed suddenly from one year to the next simply because a new manager came who succeeded to bring new programmes which the public was interested in. So the museum's type is irrelevant." Expert F had a different point of view. In his opinion, rare, uncommon, unique museums are more attractive for people than common museum types (e.g., art and history museums).

Expert $C$ thinks there are some museums (e.g., museums of history or natural science) which are more attractive to the public, which means that, in theory, they can make a bigger impact and therefore become more sustainable. On the other hand, this expert considers that museums of art, although they have fewer visitors, have a deeper impact, as the public pays more attention to what is going on in such museums.

Expert D considers that a museum's type can influence its attractiveness, the number of visitors and, hence, its sustainability, and gives as a relevant example the case of a museum of paleontology which is very specialized and addresses only a small group of interested people. However, this expert also supports the opinion that the way in which the basic exhibition and the related activities are organized could eliminate the disadvantage imparted by the museum's type.

A similar opinion to that of the experts above is also expressed by experts E and G. According to expert E "a connection or two or three are sure to exist" between the two elements, but there is no a cause-effect relationship between them (that is, a museum whose type is less attractive for the majority of the people is not necessarily unsustainable).

Summarizing the opinions expressed by the seven experts, we can assert that a museum's type can be deemed as a possible competitive advantage, but this parameter alone does not produce a significant influence on the sustainability of a museum. Therefore, the hypothesis according to which sustainability depends on a museum's type must be rejected, which is why we consider that it should not be taken into account in the elaboration of the structure of museum sustainability indicators.

\subsubsection{The Connection between Sustainability and the Use of Certain Management and} Marketing Strategies

Internationally, more and more museums are using management practices derived from the private sector to better achieve their goals. Among the management strategies used by museums are: differentiation strategy, focus strategy, international strategy, diversification of products and services, conclusion of partnerships and strategic alliances, expansion strategy, and international strategy. Some museums are also using marketing strategies that include four elements of the marketing mix (product, price, place, promotion). This tendency is fiercely criticized by some specialists who believe that a museum's purpose should not be to make money. Thus, we wanted to find out what the Romanian experts' opinions are about the possibility that the use of certain management and marketing strategies might lead to the sustainability of museums.

All seven experts we interviewed believe that sustainability is closely connected with management and marketing strategies used by a museum. Expert A justified his opinion, stating that a museum's sustainability is influenced by its capacity for creating, innovating, and offering quality services and generating its earned income, which, in turn, depend on the way the respective museum is managed. Expert B not only admits the existence of a relationship between the two factors (sustainability and strategies), but emphasizes that such strategies are absolutely required because "if you have a diverse and interesting activity, but you don't know how to make it known, then you are obviously doing it in vain". To support his opinion that implementation of a marketing strategy helps raise a museum's sustainability, expert $C$ gives as positive examples the National Art Museum of Romania and the "Grigore Antipa" National Museum of Natural History, which "have begun to grow from 
all points of view (number of visitors, diversification of their activities, increase of the impact of their programmes, attractiveness for sponsors) due to some marketing strategies together with some intelligent offering strategies". Expert D considers that the use of marketing instruments can help create an increased audience and earned income of a museum, which in turn will impact positively on the museum's sustainability. Expert $\mathrm{G}$ also strongly believes that the right management and marketing strategies can positively influence a museum's sustainability. Some examples of strategies mentioned by this expert are: diversification of products and services offered to visitors; collaboration with other institutions for organizing atypical and interesting exhibitions for visitors (like the ones with dinosaurs); marketing strategies for creating attractive products for sale; partnerships with school units for developing joint educational programs (e.g., summer school); natural environment protection by taking over the management of protected areas; and the use of renewable energy resources and advanced insulation systems.

Even though these experts admit the usefulness and necessity of the implementation of certain management and marketing strategies, they draw attention to the shortage of professionals employed in the Romanian museum's marketing departments. This shortage is generated mainly by the rigidity of the waging system in the Romanian public sector. As expert D explains, the marketing task is frequently carried out by staff who do not have the necessary training, which often leads to lower performances than museums could have. In consideration of this situation, expert A recommends the externalization of the marketing services and collaborating with firms specialized in this field. Although the externalization of certain operations can be an efficient management strategy [70], expert $B$ does not consider that this is enough: "the collaboration with specialized firms can be carried out for various events," but "a museum needs someone who should be in charge of the institution's marketing on a permanent basis."

Based on analysis of the interviewed experts' opinions and of the case studies described in the literature [71], we consider that the management and marketing strategies applied by museums have an influence on their sustainability. The disadvantage of a museum's less attractive type can be overturned and the results obtained by the museums whose type is a strong point can be enhanced by adopting appropriate strategies. The appropriateness of specific strategies depends on the internal and external factors of a museum [72]. To develop these strategies, a museum first should analyze its environment by using tools such as: SWOT Analysis (Strengths, Weaknesses, Opportunities, Threats), PEST Analysis (Political, Economic, Social and Technological analysis), and Porter Five Forces analysis [73]. However, unlike the size of the collections, the application of adequate strategies represents a variable which depends on the management and administration of a museum. In addition, the strategies used by a museum influence other elements, such us: number of visitors, earned income, total income, community engagement, heritage preservation, inclusion of new audiences, intercultural dialogue, and innovation. Thus, management and marketing strategies applied is a general, indirect factor of influence for museum sustainability. For this reason, this influence factor will not be included separately in the structure of the indicators designed for museum sustainability measurement.

\subsection{Measuring Museum Sustainability}

The majority of the experts interviewed (five of seven) believe that the number of visitors and a museum's earned income can represent indicators for measuring a museum's sustainability, but these two criteria alone are not enough to categorize a museum as sustainable or not. Thus, expert A added to the list of indicators "the extent to which a museum uses renewable resources"; expert B thinks that one should also take into account "the opinion of the public of the museum"; expert F believes that the number of cultural activities organized by a museum can reflect its sustainability; and expert $C$ discusses the necessity of carrying out qualitative studies to assess the visitors' satisfaction with a museum's services. Whereas expert $C$ considers that, although some museums have good visitor numbers, they are not sustainable, experts $D$ and $G$ believe that the number of visitors is the chief indicator in measuring the sustainability of a museum. Expert D also mentions other indicators, 
such us: the number of publications (books, brochures, catalogues, and albums) sold, the number of promotional souvenirs sold, and the number of references to the museum in the mass media and online media. Expert E accepts that the number of visitors and a museum's earned income are elements upon which sustainability is assessed, emphasizing that "in the near future the income factor will become more and more a Procrustean criterion."

With a view to elaborating a set of indicators which would allow the measuring of museum sustainability, the experts were asked to express their opinions on the way in which they can determine if the measures adopted by a museum have contributed to improved sustainability of that museum.

Based on the premise that a sustainable museum is a community museum, expert A considers that a museum can easily realize if the measures it has adopted have a positive effect on sustainability by observing the community and the public's reaction. More exactly, a museum is sustainable if:

(a) the annual number of visitors and the public attendance of the events and programs of the museum are high;

(b) the media and people talk about what the museum is doing (this can be quantifiable through: the number of articles published about the museum's activities, the number of mentions of the museum on Google and other search engines, the number of likes on the museum's Facebook page); and

(c) the museum is called, consulted or invited to take part in various partnerships and collaborations as a result of the fact that it "has gained a degree of credibility, an impression that it is an interesting partner who has something to offer and who is worthy of associating your image with".

The same expert also admits the usefulness of carrying out studies in connection with the quality of the services a museum offers, so as to be able to determine the impact of the actions adopted on the sustainability of a museum. Even though the concept of total quality management is little known and implemented in the Romanian museum community, this expert asserts that, at a world level, there are well established quality criteria upon which the title of the European museum of the year is based and granted. In expert A's opinion, "total quality management means that you, as a museum, offer to the public all the services possible vertically and horizontally_from the simple access to the museum, including for the disabled visitors, up to facilities for relaxation between two halls, enjoying a coffee, and to the possibility of finding all kinds of corners and creative spaces where a child can freely interact with and experiment all kinds of things, on the condition that this is offered to the child (...). The total quality management, in fact, means a series of services and benefits and advantages offered to people."

Expert B correlates a museum's sustainability with the degree to which the museum meets its community's cultural needs. These needs can be determined through sociological research. However, this expert emphasizes that museums should not only satisfy needs that are known and expressed by people, but also provide their own offerings "which might arouse some interest once the public finds out about the respective offers". Therefore, in this expert's opinion, museums play an important role in shaping visitors' tastes and preferences.

Expert C's opinion is that for any measuring of museum sustainability, both quantitative and qualitative indicators are required. Regarding the Romanian museums, this expert considers that they use chiefly quantitative indicators which relate to the visitors' dynamics and profile, whereas the qualitative studies are carried out less frequently, which, of course, is a problem (because the qualitative studies are the ones through which a museum can measure the visitors' satisfaction; also, these studies can provide important information about people's needs in connection with a museum's offerings).

Expert D does not mention quality measurement at all and lists only quantitative indicators such as the number of tickets given, the number of publications and other promotional objects sold, the number of entries to shows and other events for which no entry tickets are sold, the number of media or online mentions.

Expert E emphasizes chiefly "sustainability sustenance" and is less interested in increasing a museum's sustainability. This expert asserts that "if a major element of progress (such as the rapid 
doubling of the available exhibition space as a result of getting a new building) appears, its first effect would be a dramatic disturbance in the stability and sustainability of the previous phase, due to the disruption elements which pose a high risk to sustainability". In this expert's opinion some of the indicators that can be used to analyze if a museum is or is not on a stability trend as the premise for sustainability are the following:

- The annual number of visitors (non-payers and payers);

- The rising or falling visitor attendance curve over a medium term (in this expert's opinion, this curve should be analyzed over a period of 10 years so as to be able to conclude if the respective museum has reached the desired stability; if the trend, respectively, the visitor attendance curve over a medium term, is very jagged, chances are that something in the development of the museum is not all right);

- The equilibrium established between three categories of visitors based on venues: visitors to the exhibition on the main premises, the exhibitions outside the premises but in the same county, and the exhibitions organized outside the museum's residence county. An analysis of this indicator in correlation with the type of the museum (national, county or local) allows measuring sustainability, as it reflects the degree to which the museum is trying to cover the needs of the entire community to which it belongs (national, county or local). Thus, a museum of county relevance, which organizes exhibitions at the national level, exceeds its limits of jurisdiction, which represents "an indicator of performance". In return, for national museums organizing such exhibitions represent "an indicator of diffusion, dissemination and distribution at a general scale";

- The types of beneficiaries: This indicator is analyzed in the management report as well. Museums' beneficiaries are grouped in major categories such us: foreigners, rural or urban visitors, children or grown-ups, payers or free of charge;

- Qualitative elements, such as the impressions written by the visitors in the books of honor: For example, out of 100 messages written, 96 can be positive and the rest negative. This can be an indicator for measuring the public's satisfaction;

- The beneficiaries of the secondary products offered by the museum, such as publications and souvenirs;

- The rate of absorption of secondary products (how fast these products are turned over);

- The earned income and their proportion of the total income;

- The ratio between how much the museum collected and how much it consumed (the ratio between the effect and the effort, or the ratio of output to inputs).

According to experts $F$ and $G$, the dynamic of cultural activities carried out by a museum and their degree of diversification can reflect how sustainable a museum is. Another indicator mentioned by expert $G$ is the degree to which the maintenance costs of a museum (electricity, heat and water use) decrease from one year to another.

By combining these preliminary results of the qualitative part of this study with the notions found in the specialized literature presented in the first part of this article, we propose a system of indicators for the quantitative, objective measuring of museum sustainability. This system of indicators is described below.

\subsubsection{Quantitative Indicators for Measuring Museum Sustainability}

For the elaboration of this system of indicators we started from the premise that a strictly required condition is that this system should allow the comparability of the data collected from multiple museums. Since, as we note, sustainability is influenced by a series of factors which are independent of the management of a museum, a mere comparison of the absolute figures is not relevant for the assessment of sustainability as few or no museums are precisely similar. If museums are not $100 \%$ alike, then any comparison of the absolute figures (such as the number of visitors) will be irrelevant. 
For example, we could reach the conclusion that a museum with 1000 visitors but only two employees is less sustainable than a museum with 10,000 visitors and 100 employees.

In addition, a comparison of the annual percentage increase/decrease of the sustainability of different museums, as proposed by Adams [64], would not allow establishing a ranking of the institutions analyzed based on global sustainability, as it would take into account only the efforts and the effects obtained over a limited period of time, without taking into consideration the performances of these museums before the respective period. In such conditions, a museum that, for example, has reached a high level of sustainability will record a null or very low percent increase of its results, which implicitly would place that museum at the end of any classification based on this criterion. This obviously would be irrelevant as it would not reflect its sustainability accurately. Therefore, only by using some relative values can we obtain an accurate picture of the evolution of a museum's sustainability.

Considering the above complexities, the sustainability indicators we propose were developed in such a way as to reflect relative values (see Table 3) and thus to allow comparisons between individual museums. In addition, wherever possible, we tried to take into consideration the global effect of a phenomenon, i.e., the interaction between the four domains of sustainability. This was necessary because the actions adopted to improve any of the four pillars can create negative effects in another pillar. For example, an increased number of visitors might be generated as a result of a huge increase of expenses (such as marketing costs). This can result in increased socio-cultural sustainability (by attracting new audiences, enhancing the cultural skills and knowledge, and active involvement of the community members in a museum's activities) alongside a marked decrease in economic sustainability, which would impact negatively on the overall level of sustainability (a model of determining a museum's overall sustainability level is presented in Figure 3). For this reason, what is desired is that the positive effect should be bigger than the effort or the negative effects generated. Thus, the necessity of measuring sustainability based on efficiency indicators occurs (presented in Table 3).

In addition, from the system we elaborated we excluded a number of indicators, such as those which: (1) do not take into consideration the size of the organization and whose value can be influenced by this aspect; and (2) are relevant in theory, but in reality are difficult to measure based only on the information museums generally collect without conducting supplementary studies (for instance, the museums' carbon footprint or the time spent by the visitors in the exhibitions).

These indicators had to be excluded to avoid developing a model that can not be used by all the museums in the NNRM. Thus, the system was developed in such a way that all the necessary data for calculating these indicators be available and collectable from each museum included in the sample. Much of the data needed to calculate the indicators can be obtained from management reports and annual statistics completed by museums. Management reports contain rich information about heritage (conservation, research, restoration, new acquisitions and donations), exhibitions (inside the museum and outside the museum), educational programs (for different groups of people), events, visibility in the media, partnerships with other museums, visitors (offline and online, payers and non-payers), total revenues, earned income, expenses, human resources and volunteers [74]. The annual statistics, filled by museums at the request of the National Institute of Statistics, include issues relating to: museums' heritage; exhibitions, visitors and publications; other specific activities of museums; participants in the activities of museums; and museum staff, classified by type, age and levels of education. Besides these two data sources, many museums produce their own publications which present date about their heritage conservation and restoration, and also their visitors flows [75]. Based on these aspects we have elaborated a set of 33 indicators measuring museum sustainability. These are described in Table 3. 
Table 3. Indicators measuring museum sustainability.

\begin{tabular}{|c|c|c|c|}
\hline No. & Indicators & Optimum & $\begin{array}{l}\text { Sustainability } \\
\text { Dimension }\end{array}$ \\
\hline 3 & $\begin{array}{l}\text { State of conservation: the proportion of objects which are conserved } \\
\text { perfectly }(\%) \\
\text { Storage conditions: the proportion of collections stored in appropriate } \\
\text { conditions }(\%) \text { [67] } \\
\text { The degree of heritage research: the proportion of objects pertaining to which } \\
\text { the documentation is complete }(\%)[67] \\
\text { Meeting the microclimate conditions: the number of days in which there were } \\
\text { no deviations from the optimum microclimate parameters } / 365(\%)^{1}\end{array}$ & maximum & $\begin{array}{l}\text { Cultural } \\
\text { (collection } \\
\text { storage, } \\
\text { conservation and } \\
\text { research) }\end{array}$ \\
\hline 6 & $\begin{array}{l}\text { The degree of exhibiting: (The number of objects exhibited per year * the } \\
\text { number of days of exhibition/(The number of heritage objects *365) }(\%) \\
\text { Online visibility: Number of mentions of the museum on Google/Number of } \\
\text { objects in the collection } \\
\text { Extension outside the main premises: (Number of objects exhibited outside the } \\
\text { main premises * number of days of exhibition)/(Total number of objects not } \\
\text { exhibited at the main premises * } 365)(\%)\end{array}$ & maximum & $\begin{array}{l}\text { Social and } \\
\text { cultural }\end{array}$ \\
\hline $\begin{array}{c}9 \\
10\end{array}$ & $\begin{array}{l}\text { Extension on the market: The percentage of the number of objects lent to other } \\
\text { institutions from the total of objects not exhibited (\%) [67] } \\
\text { Visibility in the media: number of mentions in the press per year/Number of } \\
\text { events organized annually } \\
\text { Attractiveness of the museum's collections: Number of visitors/objects exhibited } \\
\text { Assessment of the museum by the visitors: Number of positive } \\
\text { impressions/Total number of impressions written by visitors in the } \\
\text { guestbook, in a year (\%) } \\
\text { Ratio of young and old staff: ratio of staff who are in the first } 10 \text { years of their } \\
\text { career to those in the last } 10 \text { years of their career (\%) [67] } \\
\text { Online accessibility of the collections: Number of objects expressed as } \\
\text { percentage from the whole collection published on-line (\%) [67] }\end{array}$ & maximum & $\begin{array}{l}\text { Social (collection } \\
\text { accessibility; } \\
\text { community } \\
\text { involvement; the } \\
\text { museum's social } \\
\text { impact) }\end{array}$ \\
\hline $\begin{array}{l}14 \\
15 \\
16 \\
17 \\
18 \\
19 \\
20\end{array}$ & $\begin{array}{l}\text { Labour productivity 1: Number of events/Number of staff } \\
\text { Labour productivity 2: Number of temporary exhibitions/Number of staff } \\
\text { Labour productivity 3: Number of visitors/Number of staff } \\
\text { Labour productivity 4: Number of online unique visitors per } \\
\text { year/Number of staff } \\
\text { Efficiency of financial resource use: Number of visitors/Total expenses } \\
\text { Efficiency of material resource use: Number of visitors/Exhibition area } \\
\text { Attractiveness of museum's electronic resources: Number of online unique } \\
\text { visitors per year/Number of posts }\end{array}$ & $\begin{array}{l}\text { maximum }^{2} \\
\text { maximum }\end{array}$ & $\begin{array}{l}\text { Social and } \\
\text { economic }\end{array}$ \\
\hline $\begin{array}{l}21 \\
22 \\
23\end{array}$ & $\begin{array}{l}\text { Voluntary involvement: Number of hours worked by voluntaries per } \\
\text { year/Number of voluntaries } \\
\text { Capital productivity: Earned income/Total objects exhibited per year } \\
\text { Consumption of financial resources: Objects exhibited per year/Total expenses }\end{array}$ & & $\begin{array}{l}\text { Social and } \\
\text { economic }\end{array}$ \\
\hline $\begin{array}{l}26 \\
27 \\
28\end{array}$ & $\begin{array}{l}\text { Consumption of electricity: Consumption of electricity/Museum's area } \\
\text { Consumption of thermal energy: Consumption of thermal } \\
\text { energy/Museum's area } \\
\text { Consumption of water: Consumption of water/(Staff + Voluntaries + Unique } \\
\text { visitors at the main premises) } \\
\text { Consumption of consumables: Expenses for consumable office materials (ink } \\
\text { cartridges, stationary, files, etc.)/Number of staff and voluntaries } \\
\text { Consumption of fuel: Consumption of fuel/No. of external events }\end{array}$ & minimum & $\begin{array}{l}\text { Natural } \\
\text { environment } \\
\text { (using the } \\
\text { resources as } \\
\text { efficiently as } \\
\text { possible) }\end{array}$ \\
\hline $\begin{array}{l}29 \\
30\end{array}$ & $\begin{array}{l}\text { Labour productivity } 5 \text { (value): Earned income/Number of staff } \\
\text { Capacity of self-financing: Earned income/Total income (\%) } \\
\text { Quantitative liquidity of merchandise (calculated individually for each type of } \\
\text { products): Annual merchandise sales (pcs.)/Quantities manufactured or } \\
\text { purchased (pcs.) (\%) } \\
\text { Value liquidity of merchandise: Annual income from merchandise sales/Value } \\
\text { of stored merchandise } \\
\text { Correlation between the number of tourists from the city or area and the } \\
\text { number of visitors of the museum (this measures the museum's contribution to } \\
\text { the economic development of the area) }\end{array}$ & maximum & $\begin{array}{l}\text { Economic } \\
\text { (efficiency; } \\
\text { economic impact } \\
\text { on the } \\
\text { community) }\end{array}$ \\
\hline
\end{tabular}

Notes: ${ }^{1}$ The sign "/" was used in the table as a math symbol, with the meaning of division. ${ }^{2}$ Supplementary research is needed to determine the optimum number of visitors per $\mathrm{m}^{2}$. This indicator cannot tend towards infinity because a museum that is excessively crowded is unable to fulfill its educational function properly, which leads to provision of low quality services and visitors' dissatisfaction. 


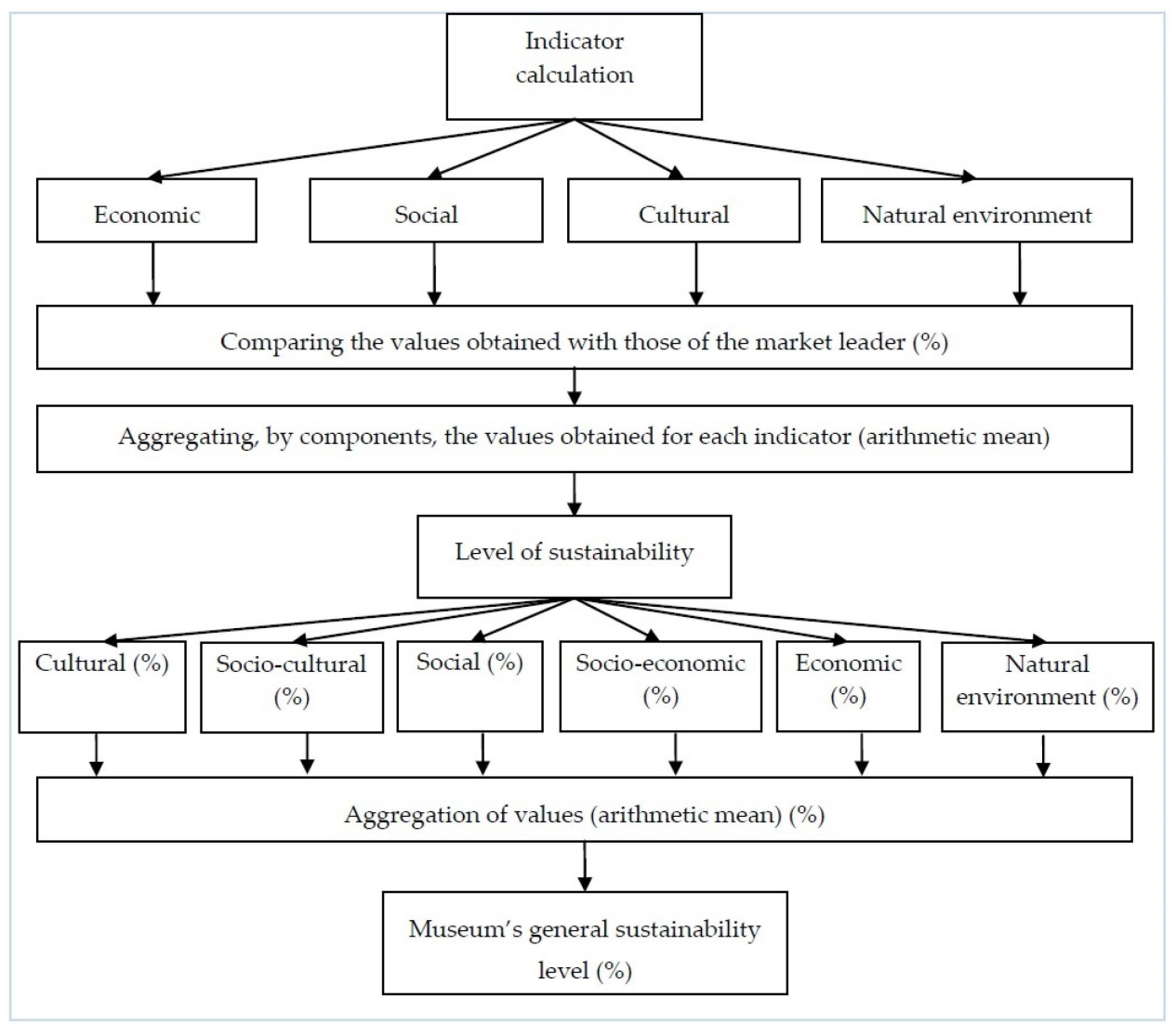

Figure 3. Model of determination of a museum's sustainability level. Source: the authors' contribution.

By using this set of indicators, a museum can assess itself either by comparing the evolution of the values recorded over a number of periods of time or by comparing its results with the average or maximum indicators recorded in the museum sector. As related to the concept of sustainability, the general goal of museums will be to obtain a maximum cultural (C), social (S) and economic (E) impact with a minimum impact upon the environment $(\mathrm{M})$. This goal can be expressed synthetically through the following equation:

$$
\text { Sustainability level }=\max (C)-\min (M)+\max (S)+\max (E) \rightarrow \max
$$

However, achieving a maximum level of sustainability is a general goal whose fulfillment cannot be evaluated without taking into account a certain reference system. For this reason any internal self-assessment made by a museum based on the indicators above must be accompanied by a comparative assessment at a sectoral level. In this way, the maximum level of sustainability will be represented by the best performances recorded by a museum. Thus, having a term of comparison, that is a standard, museums could implement SMART (specific, measurable, attainable, realistic and time-related) objectives of sustainability.

\subsubsection{A model of Determining a Museum's Sustainability}

The sustainability of a museum can be determined by comparing its performances with those obtained by other museums in a certain region or country. To accomplish this, the steps described below (Figure 3) must be followed:

(1) Calculating the sustainability indicators described in Table 3;

(2) Determining the position of the respective museum by comparing the value of each indicator (calculated in step 1) to the best value in the sector (maximum or minimum). At the end of this 
step, each indicator will be expressed as percentage based on the optimum value existing on the market; thus, a set of 33 relative indicators will be obtained;

(3) Aggregating, by domains, the values of the relative indicators calculated in step 2. This will be calculated as an arithmetic mean of the relative indicators from a certain field and will allow determining the sustainability by components;

(4) Determining the museum's general sustainability as the arithmetic mean of the sustainability recorded by components.

After following these steps, sustainability rankings including the museums in a certain country can be made. These rankings are important and relevant because they will help improve the competitiveness between museums and their performances. If at present there are few museum managers who take any regard to the issues in connection with sustainability, after these analyses are made at a sectoral level, the situation is likely to change. On the one hand, the use of this model will clear up, to a great extent, what being a sustainable museum means and offer museum staffs an effective assessment tool. On the other hand, this model facilitates the application by the museums of benchmarking, which will enable them to improve their level of sustainability. In addition, determination of a museum's sustainability according to the steps described above subsequently allows the setting of some SMART goals in the field of sustainability and the elaboration of some coherent strategies to attain these goals [76]. Finally, the most important strength of this model is the fact that it turns equilibrium across the four pillars of sustainability into a numerical indicator. Specifically, a museum achieves equilibrium when it obtains a sustainability level of $100 \%$. Thus, comparing sustainability across museums is crucial for determining the equilibrium. Without these comparisons, museums can not know when they obtain the equilibrium between the four pillars of sustainability, or how far or close they are from this state of equilibrium. Moreover, general sustainability levels of museums can be interpreted based on the scale proposed by Yigitcanlar and Dur [77]. According to these authors, sustainability levels are: low, medium-low, medium, medium-high, and high. In the model we propose, these levels can be applied as follows: [0\%-20\%]-low; $(20 \%-40 \%]-$ medium-low; (40\%-60\%]—-medium; $(60 \%-80 \%$ — - medium-high; and (80\%-100]—high.

\section{Conclusions}

The purpose of this research was, on the one hand, to identify to what extent the size, type, and management and marketing strategies applied by a museum influence its sustainability and, on the other hand, to create an instrument for measuring museum sustainability as accurately and objectively as possible, which at the same time would allow carrying out contrastive analyses at an industry level.

The results of the expert interviews show that sustainability can be influenced to a large extent by the size of a museum in terms of the material and human resources it holds, both positively, as a result of the increase of the output generated on the market, and negatively, as a result of the increase of its costs. For this reason, we considered that the measurement of sustainability must take into account this factor so as to make correct comparisons between museums. Thus, we designed indicators in such a way that their values are relative to museums' size (e.g., number of visitors/objects exhibited or number of events/number of staff).

On the other hand, the experts considered that, although the type of museum can have a positive influence on its success, it cannot be used as an excuse for its lower sustainability level in comparison with those of other museums' because, through adequate management and the use of the appropriate strategies, any museum, whatever its type, can become sustainable. As a result of this finding, we considered that all museums, irrespective of their types and across different types, can be compared by their levels of sustainability as long as their size is taken into account.

Based on the literature and experts' opinions about the factors that influence museum sustainability and the ways in which a museum can quantify if its sustainability level has increased or decreased, the second part of our paper elaborates a set of 33 indicators for museum sustainability measurement. These indicators are grouped by the sustainability dimension(s) to which they relate. 
For the cultural, social and economic pillars, indicators were created in such a way that their optimum values tend towards the maximum, given that they measure the results obtained by museums through their activities. For the environmental pillar, the optimum values of the indicators tend towards the minimum because these indicators refer to resource consumption and the impact upon the environment. After elaboration of this set of indicators, we proposed a model through which a museum's sustainability can be determined, on scale from $0 \%$ to $100 \%$, depending on the results recorded by the other museums in the market.

As no other models for identifying and measuring factors affecting a museum's global sustainability have been developed as of this writing, the results of this research contribute substantially to the literature on this topic. These results are also useful from a practical point of view, as they offer a tool for the measurement and assessment of sustainability which can be used by both museum managers and by managers responsible for decisions about the funding, management and operation of museums at the local, regional, and national levels.

However, the limitations of this research must be taken into consideration as well. In addition to the influence factors that have been identified, there might be other factors that should be considered in evaluating a museum's sustainability. In addition, further research must be conducted on some of the indicators presented above, to determine maximum levels for these indicators, as they cannot tend towards infinity (e.g., the number of visitors $/ \mathrm{m}^{2}$ ). Last but not least, future research should also focus on the practical testing of this model to assess its validity, reliability, and practical viability, after which means of improving the model might be identified.

Acknowledgments: We would like to thank the anonymous reviewers for their helpful suggestions and feedback as well as the interviewed experts for their time and valuable insights.

Author Contributions: All authors contributed equally to this work. All authors read and approved the final manuscript.

Conflicts of Interest: The authors declare no conflict of interest.

\section{References}

1. Auclair, E.; Fairclough, G. (Eds.) Theory and Practice in Heritage and Sustainability: Between Past and Future; Routledge: Abingdon, UK, 2015; p. 1.

2. Hunt, A.; Kershaw, A. Sustainable Development through Heritage and Education: The New Peterborough Effect. Rethink. Educ. 2013, 98-119. Available online: http://www.houseforculture.eu/upload/Docs \%20ACP / ACP2013WebVersionFull.pdf\#page=51 (accessed on 20 October 2015).

3. Pietro, L.D.; Mugion, R.G.; Renzi, M.F.; Toni, M. An audience-centric approach for museums sustainability. Sustainability 2014, 6, 5745-5762. [CrossRef]

4. Basu, P.; Modest, W. (Eds.) Museums, Heritage and International Development; Routledge: Abingdon, UK, 2014; Volume 1, p. 11.

5. Stylianou-Lambert, T.; Boukas, N.; Bounia, A. Politics, tourism and cultural sustainability. In Theory and Practice in Heritage and Sustainability: Between Past and Future; Auclair, E., Fairclough, G., Eds.; Routledge: Abingdon, UK, 2015; pp. 176-189.

6. Mencarelli, R.; Marteaux, S.; Pulh, M. Museums, consumers, and on-site experiences. Mark. Intell. Plan. 2010, 28, 330-348. [CrossRef]

7. Alcaraz, C.; Hume, M.; Sullivan Mort, G. Creating sustainable practice in a museum context: Adopting service-centricity in non-profit museums. Australas. Mark. J. 2009, 17, 219-225. [CrossRef]

8. Rentschler, R.; Geursen, G.M. Entrepreneurship, marketing and leadership in non-profit performing arts organisations. J. Res. Mark. Entrep. 2004, 6, 44-51. [CrossRef]

9. Ambrose, T.; Paine, C. Museum Basics, 3rd ed.; Routledge: New York, NY, USA, 2012; p. 10.

10. Donghai, S. The Concept of the Ecomuseum and its Practice in China. Mus. Int. 2008, 60, 29-39. [CrossRef]

11. Skramstad, H.; Skramstad, S. Mission and vision again? What's the big deal? In Small Museum Tolkit. Leadership, Mission, and Governance; Catlin-Legutko, C., Klingler, S., Eds.; AltaMira Press: Plymouth, UK, 2012; pp. 60-76. 
12. Camarero, C.; Garrido, M.J. Fostering innovation in cultural contexts: Market orientation, service orientation, and innovations in museums. J. Serv. Res. 2012, 15, 38-58. [CrossRef]

13. Aarts, H. Ceeste un muzeu. In Management Muzeal şi Educaţie Muzeală în România; Asociaţia muzeelor din Olanda: Amsterdam, The Netherlands, 2010; pp. 17-24.

14. Lehman, K. Australian museums and the modern public: A marketing context. J. Arts Manag. Law Soc. 2009, 39, 87-100. [CrossRef]

15. Gilmore, A.; Rentschler, R. Changes in museum management. A custodial or marketing emphasis? J. Manag. Dev. 2002, 21, 745-760. [CrossRef]

16. Lennon, J.J.; Graham, M. Commercial development and competitive environments: The museum sector in Scotland. Int. J. Tour. Res. 2001, 3, 265-281. [CrossRef]

17. Gray, C. Museums, galleries, politics and management. Public Policy Adm. 2011, 26, 45-61. [CrossRef]

18. Scott, C. Measuring social value. In Museum Management and Marketing; Sandell, R., Janes, R.R., Eds.; Routledge: Abingdon, UK, 2007; pp. 181-194.

19. McLean, F. Services marketing: The case of museums. Serv. Ind. J. 1994, 14, 190-203. [CrossRef]

20. Hume, M.; Mills, M. Building the sustainable iMuseum: Is the virtual museum leaving our museums virtually empty? Int. J. Nonprofit Volunt. Sect. Mark. 2011, 16, 275-289. [CrossRef]

21. Genoways, H.H.; Ireland, L.M. Museum Administration: An Introduction; AltaMira Press: Plymouth, UK, $2003 ;$ p. 4.

22. Grenier, R.S. All work and no play makes for a dull museum visitor. New Dir. Adult Contin. Educ. 2010, 127, 77-85. [CrossRef]

23. Zbuchea, A. Rolul strategiilor de relaţii publice într-un muzeu. In Practica Relaţiilor Publice în Muzee; Zbuchea, A., Ed.; Comunicare.ro: Bucureşti, Romania, 2014; pp. 21-32.

24. Lord, B.; Lord, G.D.; Martin, L. Manual of Museum Planning: Sustainable Space, Facilities, and Operations, 3rd ed.; AltaMira Press: Plymouth, UK, 2012.

25. Günay, B. Museum concept from past to present and importance of museums as centers of art education. Procedia Soc. Behav. Sci. 2012, 55, 1250-1258. [CrossRef]

26. Bridaa, J.G.; Meleddub, M.; Pulinac, M. Understanding urban tourism attractiveness: The case of the archaeological Ötzi museum in Bolzano. J. Travel Res. 2012, 51, 730-741. [CrossRef]

27. Foley, M.; McPherson, G. Museums as leisure. Int. J. Herit. Stud. 2000, 6, 161-174. [CrossRef]

28. Absalyamova, A.; Absalyamov, T.; Absalyamova, S. Private museums as a form of preservation of cultural heritage. ProcediaSoc. Behav. Sci. 2015, 188, 218-221. [CrossRef]

29. Svensson, E. Consuming nature-producing heritage: Aspects on conservation, economical growth and community participation in a forested, sparsely populated area in Sweden. Int. J. Herit. Stud. 2009, 15, 540-559. [CrossRef]

30. Centrul de Cercetare şi Consultanţă în Domeniul Culturii (CCCDC). Strategia Sectorială în Domeniul Culturii şi Patrimoniului Naţional Pentru Perioada 2014-2020. Available online: http:/ /www.cultura.ro /uploads/files/STRATEGIA_\%20SECTORIALA_IN_DOMENIUL_CULTURII_2014-2020.pdf (accessed on 24 November 2014).

31. Yuqin, D. The role of natural history museums in the promotion of sustainable development. Mus. Int. 2008, 60, 20-28. [CrossRef]

32. Tlili, A. Behind the policy mantra of the inclusive museum: Receptions of social exclusion and inclusion in museums and science centres. Cult. Soc. 2008, 2, 123-147. [CrossRef]

33. Stylianou-Lambert, T.; Boukas, N.; Christodoulou-Yerali, M. Museums and cultural sustainability: Stakeholders, forces, and cultural policies. Int. J. Cult. Policy 2014, 20, 566-587. [CrossRef]

34. Pencarelli, T.; Cerquetti, M.; Splendiani, S. The sustainable management of museums: Theoretical considerations and empirical evidence from marche region. In Proceedings of the 5th Advances in Tourism Marketing Conference on Marketing Places and Spaces: Shifting Tourist Flows, Algarve, Portugal, 2-4 October 2013; pp. 31-36.

35. Rădulescu, C.; Toader, R.; Boca, G.; Abrudan, M.; Anghel, C.; Toader, D.C. Sustainable development in maramures county. Sustainability 2015, 7, 7622-7643. [CrossRef]

36. Nielsen, J.K. The relevant museum: Defining relevance in museological practices. Mus. Manag. Curatorship 2015, 30, 1-15. [CrossRef]

37. Swarbrooke, J. Built attractions and sustainability. In The Routledge Handbook of Tourism and Sustainability; Hall, C.M., Gossling, S., Scott, D., Eds.; Routledge: Abingdon, UK, 2015; pp. 356-364. 
38. Chitima, S.S. Developing sustainable museums through "greening": A case study of the Zimbabwe Military Museum. In African Museums in the Making: Reflections on the Politics of Material and Public Culture in Zimbabwe; Mawere, M., Chiwaura, H., Thondhlana, T.P., Eds.; Langaa RPCIG: Bamenda, Camerun, 2015; pp. $223-245$.

39. International Council of Museums. Museums and Sustainable Development: How can ICOM Support, in Concrete Terms, the Museum Community's Sustainable Development Projects? In Proceedings of the Advisory Committee Meeting, Paris, France, 6-8 June 2011; Available online: http:/ /archives.icom. museum/download/june2011/panels/110602_\%20JM_panel1.pdf (accessed on 23 December 2015).

40. Canadian Museums Association. A Sustainable Development Guide for Canada's Museums. Available online: http://www.museums.ca/client/document/documents.html?categoryId=361 (accessed on 23 December 2015).

41. Worts, D. Fostering a culture of sustainability. Mus. Soc. Issues 2006, 1, 151-172. [CrossRef]

42. Friedman, A.J. The great sustainability challenge: How visitor studies can save cultural institutions in the 21st Century. Visit. Stud. 2007, 10, 3-12. [CrossRef]

43. Cerquetti, M.; Montella, M.M. Museum networks and sustainable tourism management: The case study of marche region's museums (Italy). Enlightening Tour. Pathmaking J. 2015, 5, 100-125.

44. Tam, S. In Museums we trust: Analyzing the mission of museums, deaccessioning policies, and the public trust. Fordham Urban Law J. 2012, 39, 849-901.

45. Kenkmann, A. Power and authenticity: Moving from the classroom to the museum. Adult Educ. Q. 2011, 61, 279-295. [CrossRef]

46. O’hagan, J.W. Art museums: Collections, deaccessioning and donations. J. Cult. Econ. 1998, 22, $197-207$. [CrossRef]

47. Kang, C.; Anderson, V.; Wu, X. Chinese perceptions of the interface between school and museum education. Cult. Stud. Sci. Educ. 2010, 5, 665-684. [CrossRef]

48. Kratz, S.; Merritt, E. Museums and the future of education. Horizon 2011, 19, 188-195. [CrossRef]

49. Buber, R.; Knassmüller, M. Approaching Museum Shop Marketing from a Strategic Perspective. In Proceedings of the 2009 ANZMAC Conference, Melbourne, Australia, 30 November-2 December 2009. Available online: http:/ / www.duplication.net.au/ANZMAC09/papers/ANZMAC2009-581.pdf (accessed on 24 November 2014).

50. Kotler, N.G.; Kotler, P.; Kotler, W.I. Museum Marketing \& Strategy, 2nd ed.; Jossey-Bass: Hoboken, NJ, USA, 2008; p. 13.

51. Gil, S.M.; Ritchie, J.B. Understanding the museum image formation process a comparison of residents and tourists. J. Travel Res. 2009, 47, 480-493.

52. Wickham, M.; Lehman, K. Communicating sustainability priorities in the museum sector. J. Sustain. Tour. 2015, 23, 1011-1028. [CrossRef]

53. Siu, N.Y.M.; Zhang, T.J.F.; Dong, P.; Kwan, H.Y. New service bonds and customer value in customer relationship management: The case of museum visitors. Tour. Manag. 2013, 36, 293-303. [CrossRef]

54. Sacco, P.L.; Blessi, G.T.; Nuccio, M. Cultural policies and local planning strategies: What is the role of culture in local sustainable development? J. Arts Manag. Law Soc. 2009, 39, 45-63. [CrossRef]

55. Plaza, B.; Haarich, S.N. The Guggenheim museum Bilbao: Between regional embeddedness and global networking. Eur. Plan. Stud. 2013, 23, 1-20. [CrossRef]

56. Joshi, P.V. Planning cultural-heritage tourism for sustainable development. Gold. Res. Thoughts 2012, 1, 1-4.

57. Bernardi, C. The sustainability of museum growth: A system dynamics approach. In Proceedings of the 24th International Conference of the System Dynamics Society, Nijmegen, The Netherlands, 23-27 July 2006; pp. 23-27.

58. Blagoeva-Yarkova, Y. The role of local cultural institutions for local sustainable development. The case-study of Bulgaria. Trakia J. Sci. 2012, 10, 42-52.

59. Friman, H. A museum without walls. Mus. Int. 2006, 58, 55-59. [CrossRef]

60. Sutter, G.C. Promoting sustainability: Audience and curatorial perspectives on the human factor. Curator Mus. J. 2008, 51, 187-202. [CrossRef]

61. Corsane, G. Using ecomuseum indicators to evaluate the robben island museum and world heritage site. Landsc. Res. 2006, 31, 399-418. [CrossRef]

62. Davis, P. New Museologies and the Ecomuseum. In The Ashgate Research Companion to Heritage and Identity; Graham, B., Howard, P., Eds.; Ashgate: Aldershot, UK, 2008; pp. 397-414. 
63. Chang, C.; Annerstedt, M.; Herlin, I.S. A narrative review of ecomuseum literature: Suggesting a thematic classification and identifying sustainability as a core element. Int. J. Incl. Mus. 2015, 7, 15-29.

64. Adams, E. Towards Sustainability Indicators for Museums in Australia; University of Adelaide: Adelaide, Australia, 2009. Available online: http://www.significanceinternational.com/Portals/0/Documents/ Sustainability_indicators_report_by_Eleanor_Adams_11January2010.pdf (accessed on 25 July 2015).

65. Brinkmann, S.; Kvale, S. InterViews: Learning the Craft of Qualitative Research Interviewing, 3rd ed.; Sage Publications: London, UK, 2015.

66. Fereday, J.; Muir-Cochrane, E. Demonstrating rigor using thematic analysis: A hybrid approach of inductive and deductive coding and theme development. Int. J. Qual. Methods 2008, 5, 80-92.

67. Onwuegbuzie, A.J.; Leech, N.L. A call for qualitative power analyses. Qual. Quant. 2007, 41, $105-121$. [CrossRef]

68. European Commission. Four Romanian Cities Short-Listed for the Title of European Capital of Culture 2021 in Romania. Available online: http://ec.europa.eu/programmes/creative-europe/news/2015/ 1211-four-romanian-cities-ecoc_en.htm (accessed on 23 December 2015).

69. Merriman, N. Museum collections and sustainability. Cult. Trends 2008, 17, 3-21. [CrossRef]

70. Salanţă, I.; Popa, M. An empirical investigation into the outsourcing logistics contract. In Proceedings of the 8th International Management Conference, Bucharest, Romania, 6-7 November 2014; pp. 350-357.

71. Pop, I.L.; Borza, A. Increasing the sustainability of museums through international strategy. Econ. Ser. Manag. 2014, 17, 248-264.

72. Vele, C.L. Organizational culture and strategy. How does it work? An empirical research. Ann. Univ. Oradea 2013, 22, 1690-1696.

73. Pop, I.L.; Borza, A. Quality improvement in museums using organizational diagnosis. Rev. Econ. Stud. Res. Virgil Madgearu 2014, 7, 75-103.

74. Popa, L.O. Raport de Activitate 2014, Muzeul Național de Istorie Naturală “Grigore Antipa”. Available online: http://www.cultura.ro/uploads/files/10_Muzeul_National_de_Istorie_Naturala_Grigore_Antipa_-_Raport _de_activitate_pentru_perioada_22_07_2014-31_12_2014.pdf (accessed on 23 December 2015).

75. Alexa, T.; Topan, D.; Negrean, I.A. Patrimoniu. Restaurări și Conservări 2007-2013; Alma Mater: Baia Mare, România, 2014.

76. Anghel, C.; Vele, C.; Toader, R.; Hahn, R.F.; Rădulescu, C.; Toader, C. The Sustainable development strategy of Baia Mare city. Ann. Univ. Oradea 2013, 1, 195-204.

77. Yigitcanlar, T.; Dur, F. Developing a sustainability assessment model: The sustainable infrastructure, land-use, environment and transport model. Sustainability 2010, 2, 321-340. [CrossRef] 